\title{
IMPLEMENTASI CORPORATE SOCIAL RESPONSIBILITY PT KAI DAOP 8 SURABAYA DALAM PROGRAM RAIL CLINIC
}

\author{
Sulistyo Rahayu Ningrum ${ }^{1}$, Fitria Widiyani Roosinda ${ }^{2}$ \\ ${ }^{12}$ Universitas Bhayangkara Surabaya \\ Email: sulistyorahayu97@gmail.com
}

\begin{abstract}
Abstrak
PT Kereta Api Indonesia (Persero) Daop 8 Surabaya melaksanakan tanggung jawab sosial terhadap lingkungan sekitarnya dalam bentuk Program Rail Clinic. Program ini merupakan implementasi corporate social responsibility perusahaan untuk mensejahterakan masyarakatnya. Program yang didedikasikan untuk masyarakat ini dalam bentuk layanan kereta kesehatan, memberikan bantuan kepada masyarakat di araea rel kereta yang jauh dari akses kesehatan. Penelitian menggunakan pendekatan kualitatif. Hasil penelitian mengungkapkan Program Rail Clinic dalam CSR PT KAI Daop 8 Surabaya menghasilkan beberapa aktivitas utama yang dijalankan yakni cause promotion, cause related marketing, corporate social marketing, corporate philanthropy, community valunteering dan socialy responsible bussines practice. Aktivitas Program Rail Clinic berhasil membantu masyarakat dari aspek pelayanan kesehatan.
\end{abstract}

Kata Kunci: Rail Clinic,CSR, PT KAI Daop 8 Surabaya

\begin{abstract}
PT Kereta Api Indonesia (Persero) Daop 8 Surabaya carries out social responsibility towards the surrounding environment in the form of the Rail Clinic Program. This program is an implementation of the company's corporate social responsibility for the welfare of its people. This program dedicated to the community in the form of a health train service, provides assistance to people in railroad area that are far from health access. This research uses a qualitative approach. The results of the study revealed that the Rail Clinic Program in PT KAI Daop 8 Surabaya's CSR resulted in several main activities carried out, namely cause promotion, cause related marketing, corporate social marketing, corporate philanthropy, community valunteering and socialy responsible business practice. The Rail Clinic program activities are successful in helping the community from the aspect of health care.
\end{abstract}

Keywords: Rail Clinic, CSR, PT KAI Daop 8 Surabaya 


\section{PENDAHULUAN}

Perkembangan Corporate Social Responsibility (CSR) ini bukan hanya sekedar hal wajib, namun merupakan cara terbaru yang dapat dijadikan manfaat lebih bagi harapan dan pencapaian perusahaan kedepannya. Kegiatan kepedulian perusahaan pada Corporate Social Responsibility (CSR) fungsi primer dalam memajukan lingkungan di wilayah perusahaan tersebut, hingga pertumbuhannya berjalan beriringan dengan kemajuan perusahaan. Program Tanggung Jawab Sosial (Corporate Social Responsibility) merupakan sesuatu yang wajib dilakukan saat ini oleh Perseroan Terbatas. Hal tersebut terdapat dalam Pasal 74 Undang -Undang Nomor 40 Tahun 2007, tentang perseroan terbatas mengenai tanggung jawab sosial dimana perusahaan yang menjalankan kegiatan usahanya di bidang dan atau berkaitan dengan sumber daya alam wajib melaksanakan tanggung jawab sosial dan lingkungan serta bagi perusahaan yang tidak melaksanakan kewajiban sebagaimana dimaksud dikenai sanksi sesuai dengan ketentuan pertauran perundangundangan (Audina,S. Aruman, 2018).

International Standards Organization (ISO) 2600, Corporate Social Responsibility (CSR) sebagai tanggung jawab suatu organisasi atas dampak dari keputusan dan aktivitasnya terhadap masyarakat dan lingkungan, melalui perilaku yang transparan dan etis yang konsisten dengan pembangunan berkelanjutan dan kesejahteraan masyarakat, memperhatikan kepentingan dari para stakeholder, sesuai hukum yang berlaku dan konsisten dengan norma-norma internasional, terintegrasi di seluruh aktivitas organisasi, dalam pengertian ini meliputi baik kegiatan, produk dan jasa.

Tanggung jawab sosial perusahaan atau yang juga dikenal dengan istilah Corporate Social Responsibility, kini telah menjadi prioritas utama para pemimpin bisnis di dunia. Corporate Social Responsibility (CSR) merupakan salah satu bentuk program tanggung jawab perusahaan terhadap stakeholder atau pemangku kepentingan. Stakeholders atau pemangku kepentingan adalah orang atau kelompok yang dapat dipengaruhi dan mempengaruhi keputusan, kebijakan ataupun setiap operasi yang dilakukan perusahaan, stakeholder dapat dikelompokkan ke dalam dua bagian, yaitu stakeholder internal dan stakeholder eksternal. Pada dasarnya ada 3 jenis tanggung jawab yang harus dilakukan perusahaan kepada pemangku kepentingan, yaitu economic responsibility, legal responsibility dan social responsibility (Lenggono, 2017).

Mayoritas perusahaan mempunyai tanggungjawab sosial (Corporate Social Responsibility) terutama perusahaan BUMN (Badan Usaha Milik Negara). Aspek tanggungjawab sosial perusahaan ini dipandang penting, karena tidak hanya mementingkan keuntungan materi bagi perusahaan, tetapi juga kepedulian kepada masyarakat untuk mencapai sukses dalam memperoleh simpati dan empati dari khalayak yang dikenal dengan corporate image. Salah satu strategi yang biasanya digunakan oleh perusahaan dalam menarik simpati publik yaitu dengan program Corporate Social Responsibility, yang merupakan bentuk tanggungjawab sosial perusahaan terhadap masyarakat dan lingkungan. Bentuk tanggungjawab perusahaan melalui program Corporate Social Responsibility (CSR) pun tidak dikhususkan untuk masyarakat luas, perusahaan harus memperhatikan masyarakat 
internal yaitu para pegawai, karena keberhasilan suatu perusahaan tidak terlepas dari hasil kerja para pegawai, maka program Corporate Social Responsibility (CSR) lebih penting untuk meningkatkan kualitas SDM yang sasarannya telah ditentukan oleh perusahaan. Program Corporate Social Responsibility (CSR) dapat diberikan kepada publik internal maupun publik eksternal sesuai dengan tema yang diselenggarakan juga sesuai dengan tujuan dari perusahaan tersebut (Evelin, 2015).

Zulhendri mengungkapkan pendapat Komisi Eropa yakni CSR dianggap sebagai sebuah konsep di mana perusahaan mengintegrasikan kepedulian sosial dan lingkungan dalam operasi bisnis dan dalam interaksi dengan para pemangku kepentingan secara sukarela yang berikut semakin menyandarkan bahwa perilaku bertanggungjawab mengarah pada keberhasilan bisnis yang berkelanjutan (Zulhendri, 2014).

CSR juga akan sangat mempengaruhi citra perusahaan jika dapat terwujud dengan baik dan sesuai tujuan. Peran CSR sangat besar bagi perusahaan, selain berperan penting dalam pembentukkan citra positif perusahaan, CSR juga menjadi wujud kepedulian perusahaan dalam memenuhi tanggung jawab sosialnya kepada para publiknya (Andraina, 2013).

Agenda perusahaan dalam kegiatan CSR menjadi isu yang cukup penting dan mendapat perhatian khusus. Banyak dampak postif yang akan diperoleh ketika CSR bisa dilaksanakan oleh perusahaan yang menjalankannya sebagai salah satu bentuk baktinya. Riswari dan Nur (2012) mengungkapkan CSR perusahaan sifatnya penting dan wajib, karena pemangku kepentingan perusahaan ingin juga mengetahui bagaimana perusahaan telah menggunakan perannya sesuai dengan kemauan stakeholder serta pertanggungjawabannya atas kegiatan tersebut dapat dibuktikan. Peraturan Pemerintah telah diatur mengenai tanggung jawab sosial perusahaan agar kualitas hidup masyarakat dalam lingkup tersebut dapat meningkat.

Hubungan masyarakat dengan perseroan diharapkan bisa menjadi hubungan yang serasi, seimbang dan sesuai dengan lingkungan, norma, dan budaya masyarakat sekitar. Peraturan tersebut merupakan salah satu bentuk ketetapan pemerintah agar perusahaanperusahaan go public, serta adanya kesadaran untuk menyelenggarakan CSR (Ekowati, 2014).

Penerapan CSR akan berdampak positif bagi kegiatan bisnis perusahaan. Keberhasilan perusahaan dalam melaksanakan CSR akan berdampak positif bagi kegiatan operasional perusahaan. keberadaan perusahaan dapat tumbuh dan berkelanjutan dan perusahaan akan mendapatkan citra yang positif dari masyarakat luas. Hal ini didukung dengan penelitian Heal dan Garret yang menunjukkan bahwa aktivitas CSR dapat menjadi elemen yang menguntungkan sebagai strategi perusahaan, dapat memberikan kontribusi kepada manajemen risiko dan CSR ini pula mampu memelihara hubungan yang dapat memberikan keuntungan jangka panjang bagi perusahaan (Fitriansah, 2015).

Di dalam implementasinya, menurut Wahyudi dan Azheri, bentuk-bentuk CSR dapat digolongkan ke dalam empat kategori. Pertama, pengelolaan lingkungan kerja secara baik. Kategori ini mencakup penyediaan lingkungan yang aman dan nyaman, sistem kompensasi yang layak, serta perhatian terhadap kesejahteraan karyawan dan keluarganya. Kedua, kemitraan antara perusahaan dengan masyarakat (khususnya masyarakat lokal). Secara 
umum, kemitraan tersebut diwujudkan dalam program community development untuk membantu peningkatan kesejahteraan masyarakat setempat jangka panjang. Melalui program ini, masyarakat diharapkan dapat menerima manfaat keberadaan perusahaan guna menopang kemandiriannya, bahkan ketika perusahaan sudah berhenti beroperasi sekalipun. Ketiga, penanganan kelestarian lingkungan. Kegiatan ini dimulai dari lingkungan perusahaan sendiri, termasuk melakukan penghematan penggunaan listrik, air, kertas, hingga penanganan limbah akibat kegiatan perusahaan agar tidak mencemari lingkungan sekitar kantor, pabrik dan lahan sekitar. Keempat, investasi sosial. Kategori ini sering diartikan secara sempit sebagai "kegiatan amal perusahaan". Sesungguhnya, istilah tersebut merujuk pada tindakan perusahaan yang memberi dukungan finansial dan non-finansial terhadap kegiatan sosial dan lingkungan yang dilakukan oleh kelompok atau organisasi lain. Pada akhirnya, kegiatan tersebut akan menunjang bisnis perusahaan karena perusahaan dapat menuai citra positif (Resha, 2014).

Melalui program CSR nama perusahaan terlihat baik dan positif di mata masyarakat serta stakeholder. Banyak dampak postif yang akan diperoleh melalui program CSR. Kemudian, perusahaan dapat menikmati pertumbuhan seiring dengan meningkatnya keuntungan dan kekuatan brand diingatan masyarakat luas. Akhirnya, terwujud citra positif mengenai hal-hal baik tentang perusahaan tersebut. Hal ini juga yang diharapkan oleh PT Kereta Api Indonesia (Persero) dengan adanya Corporate Social Responsibility (CSR) yang diinginkan dari program tersebut menjadikan investasi dalam membangun citra positif perusahaan.

Secara keseluruhan dapat dikatakan bahwa pengungkapan CSR telah menjadi salah satu sarana untuk menjamin keberlanjutan bagi perusahaan. Konsekuensi sosial dan lingkungan yang ada untuk saat ini dan masa datang telah menjadi salah satu faktor pertimbangan baru dalam pengambilan keputusan investasi oleh investor selain faktor keuangan. Pengungkapan CSR menjadi salah satu cara untuk meningkatkan nilai perusahaan (corporate value), dan hal ini akan tercermin dalam peningkatan harga saham sebagai bentuk atas reaksi investor setelah pengumuman tersebut diterima selain untuk mendapatkan legitimasi dari masyarakat. Oleh karena itu, penelitian konseptual ini difokuskan pada penjelasan tentang implikasi teoritikal konseptual dari beberapa teori yang memiliki signifikansi atas terbentuknya CSR di dalam sebuah perusahaan sebagai salah satu indikator penting dari pengungkapan kinerja perusahaan dalam rangka meningkatkan nilai perusahaan (Lindawati, 2015).

Setiap BUMN memiliki tiga misi penting yang saling terkait yakni misi sebagai unit ekonomi, sebagai stabilisator dan sebagai agent of development yang membantu percepatan pembangunan di daerah guna mengentaskan kemiskinan. Keuntungan dan kondisi pasar yang stabil dapat memudahkan BUMN untuk membantu pembangunan di daerah tempat BUMN itu beroperasi dan menciptakan hubungan baik dengan komunitas dan masyarakat lokal. Hubungan inilah yang kemudian diwujudkan oleh BUMN ke dalam program-program CSR. Salah satu BUMN yang wajib melaksanakan program-program CSR tersebut adalah PT. Kereta Api Indonesia (KAI) (Persero). Pada tahap awal, CSR diharapkan dapat membuat perusahaan terlihat baik di mata masyarakat. Tahap berikutnya, perusahaan dapat merasakan pertumbuhan seiring dengan peningkatan keuntungan dan penguatan brand di benak 
masyarakat. Pada akhirnya, terbentuklah citra positif tentang perusahaan tersebut. Hal yang sama diharapkan pula oleh PT. KAI (Persero) dengan program CSR-nya. PT. KAI (Persero) mengharapkan program CSR-nya dapat menjadi investasi pembangun citra positif (Resha, 2014)

Wujud upaya program Corporate Social Responsibility (CSR dari PT Kereta Api Indonesia (Persero) yaitu Rail Clinic. Kereta yang beroperasi di wilayah Jawa dan Sumatra ini berdesain khusus seperti klinik kesehatan, adanya kereta model ini agar dapat memberikan pelayanan dalam bidang kesehatan. Penyusunan Rail Clinic ini digagas oleh Bapak Edi Sukmoro selaku Direktur Utama PT Kereta Api Indonesia harapannya ingin memberikan pelayanan kesehatan kepada masyarakat dengan kereta yang unik dan berbeda. Kereta klinik ini menjadi kereta khusus yang berjalan di jalur kereta api agar dapat sampai melewati daerah yang susah dilewati kendaraan lainnya yang lumayan jauh dari sarana kesehatan. Pada hari ulang tahunnya yang ke 72, 28 September 2017, PT Kereta Api Indonesia (Persero) merilis kereta baru yaitu kereta klinik kesehatan yang dikenal sebagai Rail Clinic. Kereta klinik tersebut merupakan kereta lama yang dimodifikasi dengan pelayanan kesehatan, seperti pemeriksaan umum, mata, gigi, kehamilan, dan layanan farmasi. Kereta Rail Clinic menjadi kereta klinik kesehatan satu-satunya dan pertama di Indonesia yang memperoleh MURI (Haritsyah, 2017).

Kereta Rail Clinic generasi ke 4 yang saat ini dioperasikan terdiri dari beberapa unit gerbong. Terdapat dua kereta kesehatan dan dibelakangnya ada dua kereta perpustakaan yang dinamakan Rail Library. Sebagai salah satu sarana peningkatan minat baca masyarakat baik orang tua maupun anak-anak sehingga harapannya bisa ikut serta dalam mencerdaskan dan menjadikan masyarakat gemar membaca. Didalam gerbong Rail Library tersebut terdapat kumpulan buku-buku bacaan, terdapat perpustakaan online yang berisi banyak data ramah anak, disediakan sejumlah enam monitor sentuh dengan bermacam-macam buku bacaan, video inspiratif serta lagu yang memeriahkan suasana didalamnya.

Daerah-daerah yang dilintasi jalur kereta api kebanyakan tidak terhubung dengan jalan raya besar yang kemudian sulit bagi masyarakat yang dekat dengan jalur perlintasan kereta api susah dalam menjangkau pelayanan kesehatan seperti rumah sakit dan puskesmas. Melihat hal tersebut. Dengan memanfaatkan jalur kereta api, maka dimulailah pembuatan konsep kereta Rail Clinic di Bandung, pembuatan di bulan Oktober 2015 dilanjutkan di Yogyakarta. Jalur yang ada menjadi lintasan saat PT Kereta Api Indonesia (Persero) akan mendatangi ke daerah-daerah pelosok disepanjang rel kereta api yang juga susah dilalui kendaraan bermotor.

Berdasarkan atas uraian latar belakang ini lah penulis akan mendeskripsikan tentang bagaimana Program Rail Clinic dalam Corporate Social Responsibility PT KAI Daop 8 Surabaya dijabarkan menurut aktivitas utamanya Corporate Social Responsibility yang harus dijalankan sebuah perusahaan meliputi namely cause promotion, cause related marketing, corporate social marketing, corporate philanthropy, community valunteering and socialy responsible business practices. 


\section{METODOLOGI PENELITIAN}

Penelitian ini menggunakan metode deskriptif kualitatif. Metode kualitatif digunakan untuk meneliti pada kondisi objek yang alamiah, dimana peneliti sebagai instrumen kunci, Teknik analisis data bersifat induktif, dan hasil penelitian kualitatif lebih menekankan makna daripada generalisasi (Sugiyono, 2015).

Melalui wawancara dan observasi pada Humas PT KAI Daop 8 Surabaya. Menurut Komariah dan Satori mengutarakan bahwa wawancara merupakan sebuah proses percakapan dengan tujuan dalam upaya pengumpulan data maupun informasi dengan metode tanya jawab antara penulis dengan informan dalam suatu topik tertentu (Komariah \& Satori, 2012). Sedangkan, Observasi sendiri memiliki arti pengamatan secara langsung atau terjun langsung dalam pengambilan data tersebut menggunakan panca indera langsung tanpa adanya alat bantu apapun, dirangkum dari pendapat (Nazir, 2013). Observasi ini dilaksanakan dengan pengamatan langsung pada kegiatan Corporate Social Responsibility (CSR) PT Kereta Api Indonesia (Persero) Daerah Operasi 8 Surabaya selama melaksanakan magang sekaligus penelitian.

Hasil analisa dilakukan menggunakan pendapat Sugiono, yaitu, reduksi data sebuah teknik memilih pembahasan yang penting, membuat fokus serta mencari tema dan pola. Penyajian data disusun secara sistematis dengan pola hubungan yang ada disajikan dalam bentuk tabel, grafik, pemaparan dalam bentuk lainnya. Hasil penelitian menjelaskan gambaran secara utuh mengenai objek saat penelitian di lapangan ada proses menggabungkan semua data yang diperoleh menjadi satu kesatuan

\section{HASIL DAN PEMBAHASAN}

Daerah Operasi 8 Surabaya mempunyai program Rail Clinic sebagai bentuk penerapan dalam Corporate Social Responsibility (CSR). Sebagai anggota BUMN, PT Kereta Api Indonesia (Persero) turut bertanggung jawab untuk mengupayakan peningkatan status hidup dan kesejahteraan masyarakatnya khususnya diwilayah usahanya. Dengan melihat hal tersebut upaya dengan adanya program Corporate Social Responsibility dapat menunjang keberhasilan tujuan perusahaan. Menjadi salah satu program yang berbeda dari kereta kesehatan ini dibuat sebaik mungkin menjadi kereta kesehatan pertama.

Program Corporate Social Responsibility (CSR) Rail Clinic atau kereta kesehatan tersebut, yakni mencakup menurut (Situmeang, 2016) bahwa ada enam aktivitas utama CSR yang bisa dijalankan pada sebuah perusahaan, sebagai berikut :

\section{Promosi Kegiatan Sosial atau Cause Promotion}

Perusahaan memberikan dana, memberikan dukungan penuh agar memberikan pandangan kepada sumber daya di dalam perusahaan mengenai masalah sosial dan mereka ikut serta dalam mendukung, partisipasi dari masyarakat atau rekrut sukarelawan untuk kegiatan perusahaan. Pada kegiatan Corporate Social Responsibility 
(CSR) dalam program Rail Clinic yakni pemberitahuan dan perizinan kepada pemerintah wilayah setempat.

Melalui surat yang disampaikan kepada pemerintah wilayah setempat dapat mewakili dalam penyebaran informasi program rail clinic tersebut. Sehari sebelum kegiatan berlangsung, tempat sudah di siapkan dengan persiapan memasang spanduk dan x-banner di tempat pelaksanaan kegiatan bakti sosial rail clinic sehingga masyarakat yang melintasi dapat melihat info tersebut. Dukungan yang besar dari pemerintah daerah setempat juga sekaligus sebagai bentuk membantu kegiatan ini dapat dikenal masyarakat luas. Masyarakat yang jauh dari jangkauan lokasi pun, dapat datang dan ikut dalam pengobatan kesehatan gratis rail clinic.

\section{Pemasaran Terkait Kegiatan Sosial atau Cause Related Marketing}

Perusahaan mempunyai komitmen akan ikut serta memberikan perolehan untuk masalah tertentu. Saat sebuah perusahaan sudah mendapatkan sebagian dari keuntungan dari penjualan jasa atau produknya kemudian disumbangkan dalam kegiatan sosial atau tujuan amal. Salah satunya kegiatan bakti sosial yang menjadi bentuk realisasi program Rail Clinic.

Program Rail Clinic ini berlangsung dengan diselenggarakan juga acara bakti sosial dalam perwujudan santunan PT Kereta Api Indonesia (Persero) Daop 8 Surabaya kepada masyarakat sekitar stasiun dan beberapa anak-anak SD yang ikut serta. Pembagian santunan tersebut diharapkan menjadi ucapan terimakasih PT Kereta Api Indonesia (Persero) Daop 8 Surabaya pada masyarakat karena telah ikut serta menjaga keamanan area rel kereta api dan aset disekitarnya. Kegiatan bakti sosial ini dihadiri oleh perangkat desa setempat, masyarakat serta anak-anak SD. Pembagian santunan dari unit-unit kerja pada Daop 8 Surabaya membagikan bingkisan, alat kesehatan, alat olahraga, kacamata, alat mandi secara sukarela kepada masyarakat yang hadir.

Pendekatan seperti ini menjadikan masyarakat merasa diperhatikan dengan baik oleh perusahaan. Adanya rasa saling membutuhkan antara satu dengan lainnya akan terus terjalin apabila saling menaruh rasa percaya. Kegiatan bakti sosial ini menjadi wujud dari rasa kemanusiaan antara sesama manusia, bisa menguatkan kedekatan kita, rasa kasih, tolong menolong, perhatian terhadap masyarakat sekitar rel kereta api yang membutuhkan uluran tangan. Terselenggaranya kegiatan seperti ini banyak pihak yang akan mendapatkan dampak positif, banyak pelajaran yang dapat dipetik terutama pada lingkungan masyarakat serta membantu pembentukan sikap dan kepekaan sosial.

Konsep yang digunakan oleh perusahaan disini bakti sosial dengan titik berat kepada personal, institusi dan komunitas. Artiannya personal melibatkan tenaga medis serta pelayanan perorangan kepada masyarakat. Institusi melibatkan organisasi atau lembaga tertentu. Arti komunitas lebih terarah kepada masyarakat pada umumnya. Masyarakat sebagai sasaran ikut serta dalam berfikir, memberi sikap dan bertindak dalam pembangunan dan pengembangan diri sehingga kesehatannya pun lebih diperhatikan. Salah satu bentuk strategi, bakti sosial ini merupakan bentuk pengembangan dari perusahaan kepada wilayah-wilayah sekitar Daerah Operasi 8 Surabaya agar wilayah yang disinggahi rail clinic tersebut kemudian akan mempunyai 
nilai lebih dan dapat menjadi contoh untuk wilayah lainnya dalam hal, kesadaran dini untuk selalu cek kesehatan serta keselamatan di sekitar wilayah rel kereta api.

\section{Pemasaran Kemasyarakatan Korporat atau Corporate Social Marketing}

Perusahaan memberikan dukungan penuh atas kampanye perubahan perilaku agar memberikan kesejahteraan bagi stakeholder. Tujuannya meningkatkan kesadaran dalam kesehatan dan keselamatan masyarakat. Menjaga lestarinya lingkungan sekitar serta kesejahteraan masyarakat. Kesadaran masyarakat akan kesehatan dan keselamatan disekitar area lintasan rel kereta api memang harus diperhatikan oleh perusahaan setempat. Bagaimana pun mereka termasuk pemangku kepentingan perusahaan yang tiap harinya selalu beraktivitas bersama dan bersinggungan dengan bisnis perusahaan.

Masyarakat begitu antusias dengan kegiatan ini, mereka merasa diperhatikan oleh perusahaan kereta api pada wilayah Daop 8 Surabaya. Kegiatan rail clinic ini dapat diterima baik dan mendapatkan respon positif dari masyarakat yang datang. Hal ini terlihat dari sikap masyarakat yang merasa senang dan terbantu dengan adanya kegiatan pelayanan kesehatan tersebut.

Kegiatan dalam Corporate Social Responsibility (CSR) ini sudah berjalan lama dimulai pada tahun 2015. Kereta yang sudah mempunyai empat generasi ini telah melayani banyak masyarakat sekitar jalanan rel kereta api. Khusus pada Daerah Operasi 8 Surabaya melaksanakan program rail clinic dalam setahun dua kali di daerah yang berbeda.

Sosialisasi pengamanan bagi masyarakat sekitar bantaran rel kereta api juga dilaksanakan sebagai bentuk kepedulian perusahaan. Banyak kejadian yang masih terjadi seperti terserempet hingga tertabrak kereta api. Banyak faktor memang yang menjadi latar belakang kejadian-kejadian seperti itu. Bukan juga menjadi salah masyarakat, memang Tim Polsuska (Polisi Khusus Kereta Api) sebagai pemberi materi sekaligus tim lainnya bertanggung jawab penuh untuk memberikan edukasi serta sosialisasi mengenai hal tersebut. Rambu-rambu sudah terpasang pada tempatnya, alarm kereta akan segera melintas pun dari jarak radius 5 meter sangat terdengar kencang. Perhatian dan kewaspadaan dari masyarakat pun juga wajib dievaluasi, apakah sudah sesuai dengan harapan perusahaan.

Menjadi tanggung jawab penuh bagi perusahaan jika terjadi kecelakaan yang menimpa masyarakat di perlintasan kereta api. Maka dari itu, memupuk kesadaran masyarakat akan hal itu memang cukup sulit. Dengan masyarakat yang memiliki sudut pandang berbeda-beda disetiap individu. Banyak pendapat yang masuk kepada peniliti mengenai tidak berhati-hatinya mereka saat berada pada perlintasan kereta api. Saat palang pintu sudah tertutup masih saja ada yang berani menyebranginya, mereka melakukan itu karena sebab tergesa-gesa, pada pendapat masyarakat yang lain berpikiran kereta masih jauh jangkaunnya. Pemikiran seperti inilah yang harus menjadi perhatian khusus bagi Daop 8 Surabaya disini untuk memberikan penjelasan. 


\section{Kegiatan Filatropi Perusahaan atau Corporate Philanthropy}

Perusahaan memberikan dukungan berupa donasi secara langsung. Sumbangan amal, sering berupa hibah tunai, donasi atau bentuk barang. Sumbangan tersebut dapat berbentuk bingkisan, uang tunai, paket bantuan, pelayanan secara cuma-cuma, menawarkan dan mengijinkan fasilitas dan saluran distibrusi serta penggunaan peralatan yang dimiliki perusahaan untuk kegiatan sosial.

a Kerjasama Dengan Sekolah Dasar Terdekat

Kerjasama dengan sekolah dasar dapat juga menarik perhatian khalayak. Strategi kali ini dapat dikatakan strategi yang bisa memeriahkan suasana saat berlangsungnya acara. Anak-anak dengan segala kehebohannya bisa menularkan semangatnya kepada banyak orang. Dengan mengundang anak-anak sekolah dasar ini, dapat menjadi salah satu upaya suksesnya kegiatan dalam bakti sosial Rail Clinic, mereka tidak hanya mendapat souvenir gratis saja melainkan ibu dokter gigi juga sukarela menjelaskan mengenai kesehatan gigi, serta ibu dokter mata menerangkan mengenai mata yang kemudian terdapat sesi pembagian kacamata gratis bagi anak-anak penyandang mata minus. Kegiatan pertama tentang kesehatan gigi, anak-anak sekolah dasar tersebut diajak praktek langsung, setiap anak mendapat satu starter kit sikat gigi lengkap dan memulai untuk menirukan arahan dari ibu dokter gigi. Dilanjut pemeriksaan mata yang kemudian pembagian kacamata baca anak bagi yang matanya minus.

Tidak sampai disitu, anak-anak selanjutnya diantarkan menuju kereta Rail Library dimana kereta ini menjadi kereta pustaka yang lengkap dengan buku bacaan segala macam ilmu pengetahuan. Berbondong-bondong mereka menyerbu gerbong kereta tersebut, antusias untuk segera melihat interior kereta yang unik tersebut dan membaca buku-bukunya. Nampak anak-anak ada yang ramai dibagian buku-buku cerita, berkerumun di monitor layar yang menyediakan berbagai macam video edukasi, serta yang lainnya sedang melihat-lihat interior kereta. Dengan ikut sertanya anak-anak Sekolah Dasar dapat menarik perhatian media sebagai bahan publikasi. Suasana semangat dan gembira sangat nampak dari paparan muka mungil anak-anak tersebut. Mereka senang dengan gerbong kereta yang disulap sebagai ruangan ramah anak, mulai dari ruang pemeriksaan yang nyaman, tenang serta perpustakaan yang dilengkapi ratusan buku anak, permainan, video edukasi menambah sukacita anak-anak Sekolah Dasar tersebut.

b Dua Gerbong Kereta Yang Unik

Membuat puskesmas keliling dari modifikasi dua gerbong kereta api, mempunyai tujuan supaya daerah yang dituju dapat dijangkau oleh kereta. Desain gerbong yang berbeda dengan kereta pada umumnya, cukup dapat menarik perhatian khalayak. Mereka antusias berbondong-bondong masuk dan melihat interior yang unik yang jarang dimiliki kereta-kereta lain. Gerbong yang berjumlah 4 (empat) tersebut mempunyai desain berbeda. Interior didalamnya diubah menjadi gerbong VIP dengan berbagai fasilitas pendukung yang mumpuni. 
Cek kesehatan yang unik dan berbeda dari biasanya. Pemeriksaan kesehatan ini dilakukan dilakukan tidak pada ruangan khusus seperti pada klinik ataupun rumah sakit. Melainkan didalam gerbong kereta api yang di rubah dengan desain yang menyerupai klinik kesehatan, biasanya gerbong-gerbong kereta tersebut hanya untuk pelayanan angkutan penumpang, dan saat ini hadir dengan kesan yang berbeda. Di dalamnya terdapat poli-poli pengecekan, seperti poli gigi, mata, umum serta ruangan cek kesehatan lainnya. Pada poli umum disediakan 2 ruangan khusus, terdapat tempat tidur untuk cek pasien dan ruangan dokter. Banyak pemeriksaan yang bisa dipilih oleh masyarakat, meliputi cek darah, gula, fisik serta hanya konsultasi kepada dokter pun akan dengan baik dilayani. Pada ruangan diujung depan kereta merupakan tempat seperti apotek untuk pengambilan obat yang sudah diresepkan oleh dokter.

Kemudian lebih kebelakang lagi, melihat 2 gerbong selanjutnya kita akan tertarik lagi untuk mengintipnya, karena gerbong satu ini cukup istimewa dengan interior yang sangat mendukung, yaitu gerbong perpustakaan atau dikenal Rail Library, sudah pasti di sana terdapat banyak buku bacaan dari semua genre tersedia. Tersusun rapi di rak-rak buku yang dipasang di sudut-sudut pinggir dengan tengah menjadi tempat bersantai membaca buku sambil duduk-duduk manis. Bukan hanya itu didalam kereta perpustakaan ini dapat mengakses monitor sentuh edukatif yang sudah disediakan sebanyak 6 monitor sebagai sarana anak-anak jika ingin belajar atau menonton video edukatif yang sesuai dengan tumbuh kembang mereka.

Unik, menarik dan berbeda. Tampilan dari luar sama seperti kereta pada umumnya, yang perlu diketahui dari kereta Rail Clinic ini jika dalam operasinya di sepanjang perjalanan menuju lokasi kegiatan sirine kereta tak kunjuug dihentikan. Pada kereta ini menggunakan sirine yang sama seperti di ambulan yang berbunyi seiring kereta berjalan, ini juga unik dan membuat masyarakat yang ada di sekitaran rel tertegun menengok dari mana sumber suara sirine cukup keras itu berasal. Ketika telah melewati jalur rel yang disepanjang jalannya terdapat rumah-rumah warga, mereka pun sontak memperhatikan, mengabadikan, dan memberikan sambutan yang ramah kepada kereta kesehatan ini.

\section{Pekerja Sosial Kemasyarakatan Secara Sukarela atau Community Valunteering}

Perusahan memberikan bimbingan semangat kepada stakeholder yang memberikan waktunya untuk kontribusi kepada perusahaan. Mendukung karyawan, stakeholder untuk menyisihkan waktunya secara sukarela sebagai relawan kegiatankegiatan perusahaan.

\section{a Menggandeng Komunitas Pecinta Kereta Api}

Sekelompok orang-orang yang mempunyai tujuan dan harapan yang sama serta berisikan anggota yang mempunyai pandangan sama akan suatu hal. Adanya komunitas membentuk peran tersendiri bagi sebuah perusahaan. Kekuatannya dalam membentuk massa sangat diandalkan. Prinsipnya sebuah komunitas adalah membentuk kelompok sendiri, berwal ketika individu yang mempunyai hobi, 
kesukaan, ketertarikan pada hal yang sama. Tanpa menjadi kewajiban yang diharuskan oleh pihak manapun, mereka berkumpul dan menentukan visi misi yang sama untuk membantu dan saling mendukung apa yang mereka senangi.

Salah satunya komunitas Kereta Api yang ada di wilayah Daerah Operasi 8 Surabaya yang senantiasa dalam kegiatan ikut serta membantu dalam berbagai hal untuk mesukseskan kegiatan tersebut. Mereka ikut andil bukan hanya sebagai panitia, tetapi dukungan kuantitas merupakan kekuatan dalam penyebaran informasi lebih cepat, penanganan saat dilapangan lebih cepat teratasi karena tim yang banyak dan bekerja sistematis. Mereka datang dari berbagai macam komunitas yang masih dalam satu lingkup pecinta kereta api. Dalam komunitas tersebut terdapat koordinator yang bertugas mengatur anggotanya dan memberikan arahan pasukan untuk datang dan membantu kegiatan-kegiatan di Daop 8 Surabaya. Dari berbagai sudut kota dalam Daerah Operasi 8 Surabaya menghadiri atas permintaan Manager Humas yang mengajak agar lebih meriah dan menarik perhatian lagi dari acara ini. Karena dengan partisipasinya kegiatan tersebut terekspos secara menyeluruh dari berbagai penjuru asal mereka, mengenalkan Rail Clinic bukan hanya pada saat itu, tetapi dimanapun dan kapanpun publikasi dari ingatan anggota komunitas pecinta kereta api ini akan melekat.

Dengan melihat fakta bahwa setiap orang didalam komunitas tersebut memiliki satu akun sosial media yang bertajuk mengenai pecinta kereta api tersebut, semua kegiatan pada hari itu tersampaikan dan terpublikasi dengan baik dalam dokumentasinya. Masyarakat luas yang tidak berada pada wilayah tersebut juga dapat menjangkau informasi tersebut. Sikap tanggap dan rela membantu dalam hal apapun itulah yang kemudian membuat tim Humas Daop 8 Surabaya selalu mengikutsertakan mereka dalam berbagai acara atau kegiatan kantor. Gotong royong, cepat beradaptasi, kompak, semangat, hal-hal tersebutlah yang dapat mereka tularkan kepada semua orang.

b Publikasi Media Sosial Tim

Kegiatan Corporate Social Responsibility dalam Program Rail Clinic ini banyak menggandeng stakeholder perusahaan. Tidak hanya melalui media, penyebaran dan pengenalan informasi mengenai program tersebut juga dilakukan oleh berbagai pihak. Melihat poin-poin tersebut mengenai strategi dalam memperkenalkan Program Rail Clinic tersebut. Bahwa peran praktisi Public Relations sudah memaksimalkan untuk membantu program ini dikenal masyarakat.

Panitia yang ikut serta bukan hanya bertugas saat kegiatan berlangsung. Melainkan mereka juga sebagai garda terdepan dalam penyebaran informasi kepada masyarakat luas melalui sosial media, bahkan dari mulut ke mulut perihal kegiatan Rail Clinic ini. Efektifnya publikasi dari internal menjadi salah satu strategi yang tepat, dikarenakan mereka memahami bagaimana acara itu dilangsungkan. Sebagai internal perusahaan, tugas wajib menjadi penyebar informasi mengenai kegiatan yang sedang berlangsung itu merupakan suatu hal yang diharuskan. Karena, peran media cetak ataupun online tidak bisa juga diandalkan sebagai satu- satunya yang 
digunakan untuk publikasi. Justru, pihak internal meliputi karyawan perusahaan harus ikut andil memberikan arahan, sosialiasi positif serta ajakan untuk sedikit waktunya melihat aktivitas perusahaan tersebut kepada khalayak amaupun masyarakat disekelilingnya.

c Mengundang Wartawan dan Siaran Pers

Kegiatan dalam program Corporate Social Responsibility (CSR) merupakan tolak ukur dalam meningkatkan nama baik suatu perusahaan. Bagaimana perusahaan itu ikut mengembangkan masyarakat, terutama komunitas disekitarnya, akan berpengaruh terhadap citra perusahaan itu sendiri. Tanggung jawab perusahaan merupakan kegiatan bakti perusahaan terhadap masyarakatnya. Melalui sebuah komunikasi yang baik kegiatan ini akan diinformasikan oleh karyawan, masyarakat, media, komunitas serta instansi terkait.

Informasi yang akurat dan terpercaya harus terus di tingkatkan agar publik bisa mengetahui dan memahami perusahaan bersangkutan. Kegiatan humas yang telah dilaksanakan sesuai programnya akan segera dibagikan informasi terbarunya kepada masyarakat. Praktisi Public Relations harus menjadi contoh yang baik dalam mengkomunikasikan hal apapun, agar tidak akan ada isu-isu negatif menerpa perusahaan. Media salah satunya yang berperan juga dalam perantara perusahaan dengan publiknya membantu kerja Public Relations. PT Kereta Api Indonesia (Persero) khususnya di Daerah Operasi 8 Surabaya membutuhkan banyak peran media. Public Relations harus melakukan berbagai macam kegiatan menggunakan media terhadap publik-publiknya sebagai bentuk penyampaian informasi. Seorang praktisi Public Relations dalam menjalankan kegiatan ini dapat berupa komunikasi tatap muka dengan media internal seperti majalah perusahaan. Dalam kegiatan eksternal yang menyangkut kepentingan luas dan sebagai bentuk meningkatkan reputasi perusahaan, praktisi Public Relations perlu menggandeng media massa sebagai sarana menginformasikan mengenai perusahaan.

Dalam konteks ini, Humas Daerah Operasi 8 Surabaya selalu menjadikan media sebagai sahabat setia dalam setiap kegiatan perusahaan. Karena dalam setiap kegiatan sasaran utamanya adalah publiknya, supaya dapat diketahui bagaimana situasi, keadaan yang sedang ada di perusahaan. Media massa seperti koran, radio, televisi, media online sangat mempunyai pengaruh yang besar terhadap opini publik. Pembentukan opini publik muncul ketika media massa memegang peran penting sebagai penyedia informasi terhadap publik, menimbulkan citra terhadap perusahaan. Informasi yang diberikan oleh praktisi humas ke media harus bisa dipertanggungjawabkan kebenaran datanya.

Humas Daerah Operasi 8 Surabaya dalam kegiatan Corporate Social Responsibility ini juga serta mengundang awak media dan wartawan untuk meliput, agar dapat mempermudah informasi mengenai kegiatan Rail Clinic tersebut disiarkan kepada masyarakat luas. Media-media tersebut sudah terkumpul pada media grup whatsapp, kemudian Manager Humas Daop 8 Surabaya apabila akan menyampaikan informasi penting segera dilakukan tanpa harus bertatap muka, 
sehingga lebih efisien mempersingkat waktu dan mempermudah jalannya hubungan baik dengan media-media perusahaan.

Dalam pengaplikasiannya, Humas Daerah Operasi 8 Surabaya mengundang sehari sebelum kegiatan berlangsung. Melalui press release yang sudah dibuat kemudian dibagikan kepada wartawan yang hadir dalam kegiatan Rail Clinic tersebut, sebagai pedoman dan tuntunan wartawan dalam menyampaikan informasi pada media mereka. Sekaligus Manager humas sebagai kunci utama dalam kegiatan Corporate Social Responsibility tersebut juga menjaga erat dan rekat hubungan dengan media, apabila ada kegiatan-kegiatan yang bersifat mendadak dan terbaru, media juga loyalitas untuk menyesuaikannya.

Loyalitas berarti mereka para awak media dengan senang hati akan selalu menghadiri undangan Manager Humas Daerah Operasi 8 Surabaya. Perihal informasi-informasi terbaru mengenai perusahaan meliputi kebijakan baru, info tiket, penumpang kereta api dan lain sebagainya semua akan di buat press release yang kemudian dibagikan kepada awak media sebagai sarana mereka menyampaikan informasi terhadap stakeholder atau pemangku kepentingan perusahaan diluar sana.

\section{Praktik Bisnis Yang Memiliki Tanggung Jawab Sosial atau Socially Responsible Bussines Practice}

Perusahaan memakai aktivitas sebagai investasi dalam upaya mendukung masalah sosial agar masyarakat merasakan kenyamanan dan lingkungan tetap terjaga. Pengembangan macam-macam program sebagai pencapaian tujuan yaitu tercipta kesejahteraan masyarakat. Sebagai salah satu bentuk perusahaan memberikan kesejahteraan kepda masyarakatnya, membuat kegiatan Corporate Social Responsibility (CSR) yang dilakukan dalam berbagai bentuk salah satunya Program Rail Clinic, sebagai berikut :

Program Rail Clinic di Stasiun Babat Lamongan

Bentuk perhatian khusus melalui Corporate Social Responsibility (CSR), Daerah Operasi 8 Surabaya melaksanakan kembali kegiatan rutinnya yaitu kegiatan Bakti Sosial kesehatan gratis dengan hadirnya Rail Clinic pada Stasiun Babat, Kamis 7 November 2019. Sebagai bentuk peringatan Hari Pahlawan juga yang akan segera datang, bersamaan dengan acara ini diselenggarakan agar tetap ingat bagaimana perjuangan pahlawan dahulu kala mempertahankan tanah kita, jikalau tidak apalah yang tersisa untuk kita saat ini.

Dalam kata sambutannya, yang mewakili perusahaan yakni Deputy EVP Daop 8 Surabaya Bapak Djainuri menyampaikan agar nanti kegiatan Rail Clinic ini dapat memberikan manfaat khususnya dalam hal kesehatan kepada masyarakat di sekitar Stasiun Babat. Pelengkap dalam kegiatan ini, para panitia yang menjadi petugas layanan memakai baju juang tempo dulu. Terdapat juga manusia robot merah putih yang memeriahkan suasana pada hari itu memberikan semangat kepada anak-anak yang akan periksa kesehatan agar berani dan tidak takut. Bukan hanya itu saja, macam-macam souvenir dibagikan secara cuma-cuma kepada masyarakat yang hadir, terdapat pula 
balon-balon yang langsung menjadi rebutan anak-anak. Sangat dirasakan atmosfer kebahagiaan dan keceriaan dari mereka.

Pemeriksaan pada kereta kesehatan meliputi pelayanan utama atau primer seperti periksa umu, gigi, ibu dan anak, mata dan cek gula, asam urat, kolestrol. Pada kesempatan lain, panitia juga menyempatkan untuk memberikan sosialisasi dan pencerahan mengenai keselamatan keamanan dalam perjalan di kereta api, yang disampaikan oleh unit pengamanan kereta api (Polsuska). Tidak hanya pengobatan gratis dan penyuluhan saja, PT Kereta Api Indonesia (Persero) Daerah Operasi 8 Surabaya juga membagikan alat bantu penglihatan berupa kacamata gratis untuk 66 siswa-siswi, yang tediri dari 25 siswa SDN Banaran I, 25 siswa SDN Banaran II, dan 16 siswa SDN Babat 08. Kemudian dilanjut dengan pembagian kacamata kepada siswa yang belum pernah periksa mata sebelumnya. Selanjutnya, PAM Daop 8 Surabaya memberikan peralatan olah raga kepada pihak SDN 8 Babat dan Karang Taruna Remaja Gilang KA, berupa 4 buah sepak bola, 4 buah bola voli, dan 1 net.

Kegiatan tersebut apabila dipersiapkan dengan baik dan tersusun rapi maka semuanya terlaksana sesuai agenda yang sudah direncanakan. Setiap persiapan selalu membutuhkan ide yang matang agar saat pelaksanaannya nanti akan berjalan sesuai rencana. Kegiatan Corporate Sosial Responsibility Rail Clinic ini pun melewati proses persiapan yang cukup panjang. Perhatian yang khusus di setiap kegiatan yang akan diselenggarakan itu penting, supaya terfokus hanya pada kegiatan itu serta sesuai dengan rencana diawal.

\section{PENUTUP}

Berdasarkan hasil penelitian yang dilakukan oleh penulis di PT Kereta Api Indonesia (Persero) Daerah Operasi 8 Surabaya tentang implementasi Corporate Social Responsibility PT KAI Daop 8 Surabaya dalam program rail clinic dapat disimpulkan sebagai berikut :

Cause promotion, perusahaan melakukan pemberitahuan dan perizinan kepada pemerintah wilayah setempat. Cause related marketing, dengan menyelenggarakan kegiatan bakti sosial kepada masyarakat sekitar stasiun. Corporate social marketing dengan edukasi mengenai keselamatan disekitar rel kereta api sebagai bentuk kepedulian perusahaan. Corporate philanthropy, melakukan kerjasama dengan sekolah dasar terdekat. Tujuan memperkenalkan kereta api pada siswa dengan rangkaian gerbong kereta yang unik menarik perhatian mereka. Community valunteering, mengajak para komunitas kereta api, para tim karyawan serta wartawan sebagai media publikasi program Rail Clinic dan activitas socialy responsible bussines practice berlangsungnya kegiatan Rail Clinic di Stasiun Babat Lamongan pada 7 November 2019 disambut antusiasme masyarakat sekitar stasiun dengan baik.

Implementasi program Corporate Social Responsibility (CSR) Daerah Operasi 8 Surabaya dalam program Rail Clinic mendapat respon positif dari masyarakat. Hal ini dapat dilihat dari sikap yang ditunjukkan masyarakat Stasiun Babat Lamongan yang sangat senang dengan adanya program Rail Clinic tersebut, sebab masyarakat terbantu dalam akses cek kesehatan secara gratis. 
CSR salah satu komitmen Badan Usaha Milik Negara untuk kesejahteraan komunitas dalam praktik bisnis yang baik. Tujuannya untuk meningkatkan hubungan perusahaan dengan masyarakatnya. Merangkul, memberi sosialisasi, arahan kepada masyarakat, selalu memberikan layanan terbaik, hal tersebut merupakan sebuah perhatian khusus yang diharapkan oleh khalayaknya. Apalagi masyarakat disekitar stasiun bahkan pinggiran rel kereta api, mereka hanya ingin dianggap keberadaannya, dirangkul dan diberikan tempat untuk saling bertukar pikiran satu dengan lainnya.

Adanya program ini dapat meningkatkan taraf kesehatan masyarakat Indonesia. Kereta Rail Clinic ini menjadi program yang dapat menjangkau masyarakat disekitaran rel kereta yang masih jauh jangkauannya dari layanan kesehatan dan transportasi massa.

\section{REFERENSI}

Andraina, S. (2013). Aktivitas Corporate Social Responsibility (CSR) Sebagai Upaya Dalam Meningkatkan Citra Perusahaan (Studi Pada Pt Energi Mega Persada Bentu \& Korinci Baru Di Pekanbaru). Universitas Riau.

Audina,S. Aruman, A. (2018). Strategi Media Relationsdalam Program Csr Geopark Ciletuh: Studi Pt Bio Farma volume 1 nomer 2. Stikom London of Public Relations.

Ekowati, dkk. (2014). Pengaruh Profitabilitas, Likuiditas, Growth, dan Media exposure Terhadap Pengungkapan Tanggung Jawab Sosial Perusahaan: Studi Pada Perusahaan Manufaktur Yang Teraftar di BEI Tahun 2010-2012. Simposium Nasional Akuntansi XVII Mataram.

Evelin. (2015). Strategi Corporate Social Responsibility PT. Kereta Api Indonesia (Persero) Melalui Kegiatan Pekan Olahraga Kereta Api. Universitas Islam Bandung.

Fitriansah, A. (2015). Analisis Penerapan Corporate Social Responsibility Pada Pt. Kereta Api Indonesia (Persero) Divisi Regional 3 Sumatera Selatan. Universitas IBA Palembang.

Haritsyah, D. (2017). Evaluasi Pelaksanaan Program Bakti Sosial Rail Clinic di Bandung \& Yogyakarta sebagai Program Corporate Social Responsibility PT Kereta Api Indonesia (Persero) Periode 2016-2017. Universitas Muhammadiyah Yogyakarta.

Komariah \& Satori, A. (2012). Metodologi Penelitian Kualitatif. Bandung: Alfabeta.

Lenggono, P. (2017). Analisis Program Corporate Social Responsibility (CSR) Marching Band PT. Pupuk Kalimantan Timur. Universitas Islam Indonesia.

Lindawati, A. P. M. (2015). Corporate Social Responsibility: Implikasi Stakeholder Dan Legitimacy Gap Dalam Peningkatan Kinerja Perusahaan. Universitas Ma Chung.

Nazir, M. (2013). Metode Penelitian. Bogor: Ghalia Indonesia.

Resha, D. (2014). Implementasi Corporate Social Responsibility dalam Membangun Reputasi Perusahaan. Universitas Sebelas Maret.

Situmeang, I. V. . (2016). Corporate Social Responsibility Dipandang Dari Perspektif Komunikasi Organisasi. Yogyakarta: Ekuilibra.

Sugiyono. (2015). Metode Penelitian Kombinasi (Mix Methods). Bandung: Alfabeta. 
Zulhendri, F. (2014). CSR (Corporate Social Responsibility) (Tanggungjawab Sosial Korporasi). Bandung: Alfabeta. 